\title{
Assessing the Impacts of Variable Input Costs on Maize Production in Cameroon
}

\author{
Elise Stephanie Mvodo Meyo ${ }^{1,2^{*}}{ }^{(0)}$, Ivette Mbey Egoh ${ }^{1}$ \\ ${ }^{1}$ Department of Agricultural Economics and Agribusiness, Faculty of Agriculture and Veterinary Medicine, University of Buea, \\ Buea, Cameroon \\ ${ }^{2}$ Foundation for Entrepreneurship, Research and Development (FERD), Akonolinga, Cameroon \\ Email: *mvodostephanie@gmail.com
}

How to cite this paper: Mvodo Meyo, E.S. and Mbey Egoh, I. (2020) Assessing the Impacts of Variable Input Costs on Maize Production in Cameroon. Agricultural Sciences, 11, 1095-1108.

https://doi.org/10.4236/as.2020.1111071

Received: September 5, 2020

Accepted: November 22, 2020

Published: November 25, 2020

Copyright (c) 2020 by author(s) and Scientific Research Publishing Inc. This work is licensed under the Creative Commons Attribution International License (CC BY 4.0).

http://creativecommons.org/licenses/by/4.0/ (c) (i) Open Access

\begin{abstract}
Agricultural inputs are necessities in a production process just as food is a necessity for human survival. Production comes with the use of inputs. The cultivation of maize in Cameroon is predominantly dominated by smallholder farmers who use traditional methods and face drudgery. The current production level of maize in the country is declining and to meet consumption requirements, huge quantities of the commodity are imported. This study questions the impacts of variable input costs on maize production. Inputs are building blocks of production costs; it is therefore important for maize farmers to be alerted on the effective use of farm inputs in order to obtain higher returns. Data were collected with the use of a structured questionnaire. They were analysed using descriptive statistics and OLS Regression techniques. Results show that on average per hectare, each maize farmer spends USD10.12 on seeds, USD28.90 on fertilizer, USD8.90 on labour, and USD13.28 on herbicides. The regression results show that estimated coefficients of unit costs of fertilizer, herbicides and labour were negative but insignificant while land and hybrid seeds were positive. Input subsidy is recommended as a policy instrument to lower prices paid by farmers.
\end{abstract}

\section{Keywords}

Inputs, Maize, Production Costs, Cameroon

\section{Introduction}

Agriculture is the pillar that sustains all other economic sectors in the African continent. It is the driver of many countries' economies and remains, in many cases, the largest provider to Gross Domestic Product (GDP). One of the fun- 
damental roles of the sector is to provide raw materials to the industries [1]. Although its importance has been proven, the sector's productivity remains low; subsistence production is dominant and about $65 \%$ of Africa's population depends on it. The main cause of this state of affairs is limited use of improved technologies in production [1] [2]. Blessed with fertile lands and regularly abundant rainfall in most regions, Cameroon produces a variety of agricultural commodities both for export and domestic consumption. Although the South West Region of Cameroon, where the Buea Municipality is located, is a highly productive agricultural region, with diversified soils, weathers and sale opportunities, many challenges keep the poverty indicators high. In this region, the agricultural sector faces the following challenges: 1 ) low production and productivity as many crops are produced below their potential $(-50 \%)$ including maize; 2) the average annual incomes earned by farmers are far below the national average; 3 ) the sector is mostly hampered by poor economic infrastructure e.g.: farm to market roads [3]. Many institutions such as the United States Agency for International Development (USAID), the International Institute for Tropical Agriculture (IITA), World Bank (WB) and the African Development Bank (ADB) in collaboration with the country's policy makers have funded projects to improve agricultural production and productivity. The South West Integrated Rural Development Project, in a bid to address drawbacks linked to low agricultural production and productivity has executed an agricultural component that focuses mostly on providing improved planting materials of major crops. To fulfill this, planting materials were subsidized; seeds producers were trained; and the project put in place a market information system [4]. In general, major planting materials provided to farmers improved remarkably the productivity and returns of smallholder farmers. The South West Region accounts for 14,100 of farm households. As in the rest of the country, small farms dominate. Approximately, $45 \%$ of farms in the area are between 0.5 - 2 hectares. About $30 \%$ are between 2 5 hectares. Due to high cost and scarcity, paid labour is barely used. Limited possibilities of having financial capital coupled with lack of credit remain a major constraint. Many smallholder farmers do not use fertilizer, agricultural chemicals and improved seeds. In the study area, only about $10.4 \%$ of farmers use any agricultural implement or equipment as compared to $55.4 \%$ national average [3].

Maize (Zea mays) or corn is a cereal crop widely grown in the world in different agro ecologies. Generally, the crop accounts for closed to 50 species with different colours, tastes, content characteristics, grain shapes and sizes. In Cameroon, maize is the top producing grain. Common varieties cultivated in $\mathrm{Ca}$ meroon include yellow, red and white species, yellow and white which are the most common varieties. Preference of either the white or the yellow varieties depends on the eating habits of the region and their food preparation processes. Similarly, industries choose the variety that suits their products' standards and markets' conditionality. Introduced in Africa in the XVI century, the grain crop 
has become one of continent's top food crops. In different parts of the world, the grains are consumed as vegetables although it is a staple. The maize grains are rich in vitamins $\mathrm{A}, \mathrm{C}$ and $\mathrm{E}$, carbohydrates, essential minerals, with $9 \%$ proteins. Very rich in dietary fibres and calories, maize is advised as an efficient source of energy [5]. The food and non-food industries make use of all parts of the crop. In Cameroon, though consumed as snack and vegetable, it is mainly consumed as a staple by households while industries used it for animal feed, beer, flour and glue production. It is mostly cultivated by small-scale farmers.

Fertilizer is mostly used in commercial maize farming [6] [7]. Inputs (seeds, pesticides and labour) are necessities in a production process. Better fertilizer application implies an upwards shift in production [8]; its low applicability results in low production, declining soil fertility and increase soil degradation through nutrient mining [9] [10]. Labour cost represents an integral part of production costs; production will be greatly affected by its variability. In many instances, higher increase in labour cost has resulted in the inability of producers to cover functioning expenses. This has led producers to contemplate alternatives such as: 1) diversifying productions to divert/spread the risk, 2) producing substitute which are less labour intensive, 3) replacing several unskilled workers with few skilled ones, and 4) adopting technology [11] [12]. Labour represents one element of production cost items which is heavily influenced by the agricultural minimum wage. Conversely, minimum wage rate does not correlate directly with the percentage increase of labour's portion of total production cost [13]. This imperfect relationship can be related to: 1) producers reducing costs by limiting their labour force through restructuring. This will lead to labour making a smaller portion of total production cost, and 2) dependence of the sector on manual labour, and this will be characterized by higher wages [11] [13].

Variable maize production costs (excluding fixed costs) consist of seed, fertilizer, herbicide, pest control, fuel, workers, and smaller other elements [14] [15]. In some farming seasons, maize production process will require increased labour given the importance of harvest. Therefore, farmers will usually make use of seasonal workers. Fertilizer rate of use remain the lowest in Sub-Saharan Africa. Furthermore, soil scientists are reporting decline in soil fertility. These together might have been influencing the crop yields and particularly those of smallholder farmers. Genetically Modified (GM) maize seed utilization has been a success in other parts of the world [16]. Since the late 1980's, many households have contemplated maize has an opportunistic cash crop which can enable to diversify their crops production profile. This move was motivated by new trends in market forces depicting the inability of current farmers to produce quantities which will satisfy the market demand made of the increasing urban population, the animal feed industries and the maize processing industries. The maize production sector is dominated by smallholder farmers who use traditional methods and face drudgery. They apply traditional techniques which lead to low land and labour productivity. The absence of resistant or tolerant local maize varieties to 
rust diseases also constitutes a constraint [17]. Due to the decline in maize production, its' consumption has far exceeded the production level and an assessment of variable input costs among other factors will guide policy making process. The overall goal of the research is to assess the impacts of variable input costs (fertilizer, seed, herbicide and labour) on maize production in Cameroon. It hypothesizes that:

1) $\mathrm{H}_{\mathrm{o}}$ : There is no significant impact of variable input costs on maize production in the study area.

Subsidiary hypothesis to be tested includes;

2) $\mathrm{H}_{1}$ : There exists a significant relationship between herbicide, land size, improved seed and labour costs and maize production.

Since inputs are building blocks of production, it is important that maize farmers be alerted on the importance and effective use of farm inputs in order to obtain high production. The purpose of this study is to encourage input subsidy as an important policy instrument in the agricultural sector to lower input prices and increase quantities produced. This study will also examine the factors that influence the low use of variable inputs. Variable inputs may be used at a low rate by both ignorant and inspired farmers. This study will provide insight on researching further into ways of boosting input use by smallholder farmers in other areas.

\section{Production of Maize}

Production (of maize) can be understood as a process of transforming inputs using factors of production into outputs. Production is regarded as processes and methods used to transform tangible inputs (raw materials, semi-finished goods, subassemblies) and intangible inputs (ideas, information, knowledge) into goods or services. According to [17], variable inputs are those whose quantity used are determined by the level of production. They are different from fixed inputs. According to [18], a variable input is a factor of production that can be changed in the short term by a company as it is considering the change in quantities produced. Cost accounting reports that producers make use of several variable inputs among which labour, material inputs, and energy. Total Variable Costs (TVC) are the sum of costs of production that vary according to output. They include expenses on raw materials water, power, labour, and etc. According to [19] [20], total cost of production is the sum of money used of the production of a product. The total cost schedule is derived from the production function of the product for a firm. But, reference [20] clearly highlights that it is the hard work and innovation of the entrepreneur involved that enable to attain lowest level of costs.

Generally, increase in input prices will reduce the quantity of inputs used in production which ultimately results to low agricultural production. On the other hand, when input prices are subsidized, they become more affordable and farmers can better utilize them to increase production. According to [8], for a given 
fertilizer application if yield improves due to better seeds, the higher the revenue to the farmers and therefore, the more affordable is fertilizer. Better fertilizer application implies an upward shift of yield response. The challenge of input use in the production process is the adequate combinations of inputs to use given multiple variable factors of production (variable inputs). Agricultural input subsidies are one of the most common subsidies employed as policy instrument in the agricultural sector. This improves the accessibility farmers have to inputs and helps to increase production and access to food [10]. When improved input prices are low (due to input subsidies) production response will greatly increase. Improved variable inputs categorized as non-labour determinants include; improved seeds of which we have hybrid seeds and open pollinated varieties-OPVs, fertilizer, insecticides, fungicides, herbicides and manure [21]. Some research reports that hybrid seeds produce higher yields compared to landraces [14]. Costs are very crucial in business decision-making as they provide floor for pricing. They enable managers to adopt sound decisions on inputs, product lines, and prices. Every entrepreneur decides on the amount of inputs to employ. The fundamental assumption is cost minimization.

\subsection{Factors Influencing Low Use of Variable Farm Inputs}

Though the use of improved variable inputs is recommended, farmers use these inputs for various reasons. Reference [22] categorizes factors that influence use of improved inputs as: institutional factors, farmer characteristics, and inputs characteristics. Farmer's features takes into consideration age, education, gender and household size. Institutional factors consider access to information, farm size, membership to association, and access to infrastructure such as farm to market roads and warehouses. Features of the production input relates to the subjective attributes of the input as understood by the farmer [21]. The characteristics of factor inputs have an influence on farmers' perception and ultimately this affect the decision to utilize these inputs in production. Four related explanations have been put forward: consumptive traits, farmer experimentation; safety-risk attributes, farmer resource endowment and/or access [4]. Most farmers prefer the cultivation of local maize varieties to hybrids given their better food processing and on-farm storage characteristics compared to hybrid varieties [23]. Low input prices will encourage farmers to buy more. With high input utilization, maize production is bound to increase coupled with good maintenance this growth in production will increase the supply and subsequently the profit. High profits will provide sufficient income to meet basic needs of farmers, thus high standards of living. In developing countries like Cameroon characterized by small holding and subsistence farming, fertilizer demand turns to be price sensitive. When fertilizer price rises in relation to the produce price, consumption tends to fall in the short-run until technological adjustments or other factors improve yield response to neutralize the effect of the price increase. The ends of high maize production will include; low maize produce prices (due to 
increase supply), maize security (enough maize to feed the growing population) and high income to farmers since demand for maize will increase. All these ends will eventually lead to high standards of living.

\subsection{Impacts on Production and Profitability}

The work of [6] attests to the issue of maize response to fertilizer through their research on maize yield response to fertilizer and profitability in Zambia. They found that, there is a significant relationship between maize yield (production) and fertilizer use (as a result of subsidy). They further established that, households that obtained fertilizer on time and used animal draft power or mechanical power in land preparation are more likely to find fertilizer use profitable (high maize production) than other groups of households located in the same district. Results of the work done by [24] support this fact through the evaluation of constraints and opportunities of maize production in the West Region of Cameroon. They found that major maize production constraints were poor access to credit facilities and high cost of farm inputs (including Labour). The study done by [25] complements this notion in the study of improved inputs use, productivity and commercialization in Uganda maize production. The results postulated that levels of fertilizer and traction use have a remarkably positive effect on yield and labour productivity but not gross profit. They also revealed that majority of farmers in Uganda do not use improved inputs in maize production to due costs and geographical location. Many researchers had carried out studies of the impacts of variable input on maize production by capturing the impacts of Total Variable Cost on Maize Production, this study is different in that it digs into the impacts of unit costs of variable inputs such as; fertilizer, seeds, labour and herbicide on maize production.

\section{Materials and Methods}

Geographical location: The study was conducted in the Buea Municipality of the South West Region of Cameroon. Buea has an estimated population of above 200.000 inhabitants constituted essentially of the Bakweri (the indigenes) in the villages and a highly cosmopolitan population.

Climate: Buea has an equatorial climate with two major seasons: a rainy season (March to October) and a dry season (November to March). Temperature ranges between $20^{\circ} \mathrm{C}$ and $28^{\circ} \mathrm{C}$; annual rainfall ranges from $3000 \mathrm{~mm}$ to 5000 $\mathrm{mm}$.

Topography and soil: The area is composed of rolling high and low lands; due to volcanic eruptions, it is made of many rocks and gravels. The soil is made of basalts caused by the first volcanic activity in the Mount Cameroon, the biggest geographical marvel of the city. The soil is also pretty rich in nutrients and facilitates the cultivation of various crops. The soil and climate are favourable to vegetation and agriculture though in some areas tilling is difficult due to the stony nature of the soil. 
Data analysis method: the linear Function (1) specified below assesses the impacts of the selected variable input costs on maize production.

$$
Q=f(F, S, L, H, L n)
$$

It is simplified into Equation (2)

$$
Q=\alpha_{0}+\alpha_{1} F+\alpha_{2} L+\alpha_{3} S+\alpha_{4} H+\alpha_{5} L d+U t
$$

where:

$\alpha_{0}, \alpha_{1}, \alpha_{2}, \alpha_{3}, \alpha_{4}, \alpha_{5}$ are parameters to be obtained using the ordinary least square techniques.

$U t=$ Error term.

$Q=$ Production level of maize during one season (one season equals 3 months) in $\mathrm{kg}$.

$F=$ Unit Cost $/ \mathrm{kg}$ of fertilizer used in one ha of maize production.

$S=$ Unit Cost $/ \mathrm{kg}$ of maize seeds used in one ha maize production.

$L=$ Unit Cost of labour/day used.

$H=$ Unit cost of herbicide/Littre used in maize production.

$L d=$ Land Size in hectares.

These are the costs of the variable inputs which the Production level $Q$ depends on. The null hypothesis was tested at $5 \%$ level of significance with t-test. Production is measured in bags of $100 \mathrm{~kg}$. Total production is used as a measure of the farmers' use of variable inputs. Unit cost of fertilizer is measured by prices of a kilogram bought; they ranged from USD0.54 to USD1.26. Unit cost of labour is measured in a day work of a labourer. It ranges from USD2.71 to USD5.42. The cost of seed is measured by the price per kilogram. It ranges from USD0.54 to USD1.81. Unit cost of herbicide is captured by the price each farmer pays for a litre of herbicide used. Land size is measure in hectares.

A Prior Expectations: In the Linear function specified above (Equation (2)), unit cost of fertilizer is expected to be negative represented mathematically as; $\alpha 1$ $<0$ and correlates with [26] who affirms that better fertilizer applications result in low prices and upwards shift in production response. Unit cost of seeds is expected to be positive. The unit cost of labour is expected to be negative; this is in line with [12] [27] who affirm that labour costs form an integral part of a producer's production costs and labour increases will directly affect production and profitability. Same explanation ties for herbicide. Land size is expected to be positive and significant.

Data: Simple random sampling was used to collect primary data from farmers in six different areas around the study area (Bomaka, Malingo, Ndongo, Bitingi village and Mile 16 village) using a questionnaire. Data were collected from sixty maize farmers; ten maize farmers from each village.

\section{Results and Discussions}

About $38.33 \%$ of the farmers are aged ranging from 36 - 50 years, this group is made up of adults who are energetic and have families to cater for. About 
$66.67 \%$ of the maize farmers are female. The female maize farmers are more than the male farmers because most males do not engage in food crop production; they focus on cash crops. The educational status of maize farmers in the study area is very diverse. About $55 \%$ of the maize farmers are married; many are Christians (93\%). Results show that land size ranges from 0.5 ha to 10 ha with the majority having land sizes of $0.5 \mathrm{ha}, 1 \mathrm{ha}$ and $1.5 \mathrm{ha}$. Total area of land dedicated to maize cultivation is 66.75 ha for the considered population, giving an average of $1.1 \mathrm{ha}$. The small land size is due to the urban population which does not permit a single farmer to hold large land and most lands are government lands. These lands are partitioned into small plots of $30 \mathrm{~m}$ by $30 \mathrm{~m}, 25 \mathrm{~m}$ by $25 \mathrm{~m}$ and $20 \mathrm{~m}$ by $20 \mathrm{~m}$ which allows farmers to get a maximum of 3 plots. About $43 \%$ of farmers worked on rented lands, $18 \%$ on bought lands, $13 \%$ on inherited, $15 \%$ on leased, $8 \%$ on pledged land while a small portion (2\%) cultivate on allocated plots. Both permanent and seasonal labour are employed. The majority of the labour is seasonal (67\%). The percentage of permanent labour employed in maize production are 3\%,5\% and 3\% in Malingo, Bomaka and Muea villages with monthly salaries of USD99.31, USD153.49 and USD90.29 respectively. The small percentages are explained by the fact that, most maize farmers serve as permanent labourers on their farms as farming is their main occupation. High percentage is employed during peak periods such as tilling, planting and harvesting. About 35\% of this seasonal labour was employed to till, $10 \%$ to plant, $2 \%$ to harvest crops, $12 \%$ to both till and clear, and $42 \%$ to both till and plant. The small percentage of seasonal labour employed to harvest is because only few farmers cultivate maize commercially on a large scale which will require additional labour in harvesting. About $86.67 \%$ of the villagers do not join efforts to work on each other's farm. The amount paid to each seasonal labourer per day ranges from USD2.71 to USD5.42 depending on negotiated arrangements.

Three types of fertilizers are used. NPK 20:10:10, UREA and Manure (fowl dung). About 33\% of maize farmers use NPK 20:10:10 fertilizer, 11.67\% of Urea is used, while only $8 \%$ use manure. Some maize farmers do not use fertilizers because of high prices and the lack of adequate financial resources. Also, most farmers do not see the need to use fertilizers because they are unaware of their positive impacts. Farmers who use manure (fowl dung) as fertilizer use a higher quantity $(520 \mathrm{~kg})$ in a hectare than urea $(127 \mathrm{~kg})$ partly because manure is cheaper to afford. Unit price of manure is USD0.65 while unit prices of both urea and NPK 20:10:10 are USD0.83 and USD0.82 respectively. Surveyed farmers spend a total of USD785.45 on NPK 20:10:10, USD105.49 on UREA and USD33.92 on manure with average cost per farmer of USD39.27, USD15.07 and USD6.78 for NPK 20:10:10, UREA and manure respectively. In villages where middle men buy improved seeds at lower prices and sell to farmers, cost of the maize seeds will be relatively high. The price of planting seeds bought by maize farmers ranges from USD0.54 to USD1.81. About $5 \%$ of the farmers buy $25 \mathrm{~kg}$ 
seeds at USD0.72, $40 \%$ of the farmers buy $188 \mathrm{~kg}$ seeds at USD0.90. Results show that herbicide use is low. Only 21 farmers out of 60 used herbicides. Two types of herbicides are used; Gramazone and Finisher. Only 5 farmers out of the 26 use Finisher while 16 farmers use Gramazone.

The predominant farming system in the study area is subsistence farming. It enables to obtain basic necessities of life such as food and income. The main problem of this farming system is reduction in soil fertility since it involves continuous cultivation of a piece of land for long time. Farmers try to handle this problem by planting cover crops (23\% of farmers), use of fertilizers ( $31 \%$ of farmers), do not practice burning on the farm (15\% of farmers), mulching along with the use of manure ( $31 \%$ of farmers). The smallest percentage of farmers (12\%) practiced shifting cultivation because lands are limited which restrain farmers moving from one farmland to the other. Some few farmers practiced commercial farming. The main problem faced by commercial farmers is the lack of farm to market roads for transportation of produce. These farmers try to handle the problem by employing man power to transport maize from farms to distances accessible by cars and pickups where the produce is finally taken to the market. Maize farmers also face insects attack (stem borers), pests such as goats, rats, birds, squirrels which destroys the plants, and overgrowth of weeds. Birds eat up maize seeds before they germinate while goats and rats eat leaves of young maize plants. Farmers try to handle these constraints by; 1) Pressing the soil very well during planting to avoid birds eating planted seeds; 2) Scare scrolls are used to prevent birds from entering the maize farm; 3) Some farmers apply Mocap (mixed with wood ash) on the apex of plants; others use Gamaline while some use natural soil to put on the apex of infected plants to fight against insect attack (stem borers); 4) Goat's faeces are robbed on the maize plants to prevent goats form destroying the plants.

Most maize harvested during march-June season was sold fresh since drying is difficult due to frequent rains. The average production of 12.2 bags (a bag weights $100 \mathrm{~kg}$ ) is brought up by 4 large scale farmers who cultivated on land sizes as from 8 ha to 10 ha. Excluding these farmers, average production would have been 4.5 bags per farmer. Each farm household consumes 2.4 bags of maize produced. Quantity consumed is about 5 times less than quantity produced. This is explained by the fact that, farmers cultivate maize in soils well pressed. Maize revenue is calculated for 47 farmers who sold theirs using by multiplying quantity by average unit price per bag which gives USD7584.02. Four variable inputs were used in maize production; labour, fertilizer, herbicide and seeds. Total costs were as follows: labour USD534.13, fertilizer USD924.86, seed USD607.20 and herbicide USD278.98. Gross margin is calculated and the profit margin is $63 \%$ return on sale.

Approximately 525 bags (100 kg each) were sold by farmers at different prices. Maize was sold at different locations including; on farm, at homes of farmers, and local markets. The highest percentage (34\%) of farmers sold their produce 
solely at the local markets. Most traders come with their bags to buy. Also, farmers sold their produces on farm because drying of maize is difficult due to too much rains and limited bands to dry maize. Various methods were used to transport maize from the farm to market such as; cars, trucks, motorbikes and pick up. There are some institutions/organizations which assist rural farmers' e.g.: cooperatives, Cooperatives and Farmers' Organizations (F.O). Unfortunately, most maize farmers are not affiliated to these institutions and as such; do not benefit fully from the services provided. Extension workers visits rate to farms is very low and even the small percentage who visits reference farms, the frequency of visit is still low. The extension workers visit to farms is low because most maize farmers plant on small land sizes ranging from 0.5 ha - 1.5 ha. Results show that there are some educational programmes for farmers like Farmer Field Schools (FFS), seminars, workshops and ECO Relief Programmes. These educational programmes enable the acquisition of good techniques of production for the improvement of productivity. Just like with extension visits, few farmers benefit from such educational programmes. Reasons being that; some farmers are not aware of these programmes, and do not feel the need to attend. Some farmers complain of not having time to devote for such programmes.

The coefficient of land size is 0.877 indicating a positive relationship between land size and maize production. The coefficient of unit cost of fertilizer is -0.043 indicating that an increase in the cost of fertilizer will lead to $4.3 \%$ decrease in maize production. The coefficient of unit cost of labour is negative $(-0.076)$ showing an inverse relationship between labour cost and maize production. The coefficient of unit cost of seeds is 0.039 which shows a direct and positive relationship with maize production.

The t-tests results are as follows: for the constant variable we fail to reject our null hypothesis as $\mathrm{t}$-cal is less than $\mathrm{t}$-tab, $1.533<1.684$. We fail to reject the null hypothesis for unit cost fertilizer since $-0.862<1.684$ and hence the result is insignificant. For unit cost of labour, $\mathrm{t}-\mathrm{cal}<\mathrm{t}$-tab, so we fail to reject the null hypothesis as the results is not significant at $5 \%$. The impact is insignificant could be due to the fact that unit cost of labour is just among one of many factors that influence maize production. We fail to reject our null hypothesis for cost of seeds since $0.720<1.684$ and hence the result is insignificant at $5 \%$ level. We fail to reject the null hypothesis for cost of herbicides since $-1.280<1.684$, and hence our result is not significant. This can be explained by the fact that unit prices of herbicide are just one of many factors that influence maize production so; the impact of unit cost of herbicide is insignificant on maize production. We reject the null hypothesis for land size used since $16.185>1.684$ as results are very significant. For the $F$-statistics, since the $F$-calculated is 72.977 and it is greater than $F$-table which is 2.45 , the overall results are significant at $5 \%$, we therefore reject the null hypothesis and our result is more than $95 \%$ reliable based on the $F$-ratio and it can be used for policy implementation.

The Durbin Watson (DW) value is 1.922. The line of best fit is considered as 
the regression line reported by the coefficient of multiple determinations R-2. Therefore, the R-2 is 0.859 shows that the regression line accounts for more than $85.9 \%$ variation in maize production which is due to changes in the independent variables.

Variable inputs are critical factors in farm production. Most maize farmers (dominated by female farmers) do not make adequate use of variable inputs like fertilizer, chemicals, seasonal labour and herbicide mainly due to high unit costs of these inputs. High unit cost reduces the quantity of inputs used in maize production thus, low maize production. Findings show that prices of the variable inputs (fertilizers, labour and herbicides) are negatively correlated to maize production. This ties with [11] [13] [28] [29] [30] who affirmed that low fertilizer use due to high prices results in low production, declining soil fertility and also increases soil degradation through nutrient mining. Though unit costs of fertilizer, labour and herbicide are negatively related to maize production, the impact of unit increase in any of these inputs will lead to fall in maize production which is insignificant. This can be explained by the fact that unit prices are just one of many factors that influences maize production. So the study of the impact of price alone on maize production excluding other determinants such as capital, weather technology educational level, extension science, quantity of fertilizer and labour employed among others leads to insignificant changes in maize production. High unit cost of maize seeds (hybrid seeds) leads to high maize production. This is in conformity with what [15] [31] [32] [33] [34] said about the success of GM (hybrid) maize seeds. Therefore, the relevance of GM (hybrid) maize technology and the role played in poverty reduction for smallholders is of particular interest.

\section{Recommendations and Conclusion}

The study examined the impacts of variable input costs on maize production in Cameroon. The objective of this study was to assess factors influencing the low use of variable inputs. Analyses revealed that unit cost of fertilizer, herbicides and labour negatively related to maize production but their impacts are insignificant. Unit prices of variable inputs are just a group of factors that affect maize production other factors include weather, educational level, extension services, capital, technology and irrigation. Unit price of seed and land is positively related to maize production. Farmers are recommended to keep farm records on inputs used, costs, productions and revenues. These records will enable farmers to assess their level of performance. They should register in Cooperatives and Farmers' Organizations (F.O). As members of these groups, they will benefit from some provisions made by the government (hoes, cutlasses, recks, diggers), farm chemicals and subsidized improved seeds. Farmers should also attend training schools and seminars. These educational facilities will equip them with production techniques like time to plant, time to fertilize crops, proper farm maintenance and the importance of using fertilizers. All these will increase pro- 
duction. The government should establish effective and efficient distribution channels to deliver farm inputs provided to target groups on time. Usually, government provisions often reach farmers when they do not need them. This will improve production and productivity. A good number of projects and programmes should be designed to encourage not only production of maize but other food crops to ensure availability of food in the community. Input subsidy (not only seed subsidy) is recommended. This will improve farmers' accessibility to inputs. Farm to market roads should also be improved.

\section{Conflicts of Interest}

The authors declare no conflicts of interest regarding the publication of this paper.

\section{References}

[1] New Partnership for Africa's Development (2003) Comprehensive Africa Agriculture Development Programme. African Union, Addis Ababa.

[2] Bamou, E. and Masters, W.A. (2007) Distortions to Agricultural Incentives in Cameroon. World Bank, Washington DC, 1-52.

[3] Besong, M.T., Bakia, B. and Chidebelu, S.A.N.D. (2009) Farming Systems Research and Extension in Developing Economies: Experiences with Low Resource Farmers in South West Cameroon. Serials Publications, New Delhi.

[4] Smale, M., Heisey, P.W. and Leathers, H.D. (1998) Maize of the Ancestors. SOWEDA FOCUS. Basic Socio-Economic Indicators of the South West Province (Baseline Survey) Final Report, Vol. 1.

[5] Food and Agriculture Organisation (2007) State of the World's Forests 2007. Food and Agriculture Organisation, Rome. http://www.fao.org/3/a-a0773e.pdf

[6] Govereh, J., Jayne, T.S., Sokotela, S. and Lungu, O.I (2003) Raising Maize Productivity of Smallholder Farmers in Zambia: What Can Fertilizer Consumption Alone Do or Not Do? Working Paper, Food Security Research Project, Lusaka.

[7] Donovan, C., Damaseke, M., Govereh, J. and Simumba, D. (2002) Framework and Initial Analyses of Fertilizer Profitability in Maize and Cotton in Zambia. Food Security Collaborative Policy Briefs 54606, Michigan State University, Michigan.

[8] Food and Agriculture Organisation (2005) Global Forest Resources Assessment. FAO Forestry Paper 147. Food and Agriculture Organisation, Rome. http://www.fao.org/3/a0400e/a0400e00.htm

[9] Byerlee, D., Anandajayasekeram, P., Diallo, A., Gelaw, B., Heisey, P.W., Lopez-Pereira, M., Mwangi, W., Smale, M., Tripp, R. and Waddington, S. (1994) Maize Research in Sub-Saharan Africa: An Overview of Past Impacts and Future Prospects. CIMMYT Economics Working Paper 94-03, International Maize and Wheat Improvement Center, El Batán.

[10] (2015)Modern Varieties: The Microeconomics of High-Yielding Variety Adoption. http://www.fao.org/3/a0400e/a0400e00.htm

[11] Bureau for Food and Agricultural Policy (2013) BFAP Baseline Agricultural Outlook, 2012-2021. https://www.bfap.co.za/bfap-baseline-2018/

[12] Hall, R. (2012) The Next Great Trek? South African Commercial Producers Move North. Journal of Peasant Studies, 39, 823-843. 
https://doi.org/10.1080/03066150.2012.677037

[13] Meyer, F. (2013) Grain Producers' Labor Cost in South Africa. [Telephonic Interview]. 6 June, Potchefstroom.

[14] MacRobert, A.L., Kosina, P. and Jones, J. (2007) What Is an OPV. Malawi. Economic Developmentand Cultural Change, 43, 351-368.

[15] Department of Agriculture, Fisheries and Forestry (2011) Trends in the Agricultural Sector. Grain SA, Pretoria.

[16] Graham, B. and Barfoot, P. (2009) Global Impact of Biotech Crops: Income and Production Effects, 1996-2007. AgBioForum, 12, 184-208.

[17] Iken, J.E. and Amusa, N.A. (2004) Review: Maize Research and Production in Nigeria. African Journal of Biotechnology, 3, 302-307. https://doi.org/10.5897/AJB2004.000-2056

[18] Adebowale, E.A (2004) Tropical Uses of Maize. Institute of Agricultural Research and Training, Ibadan.

[19] Variable Inputs (2016). http://www.amosweb.com/

[20] Samuelson, P. and Nordhaus, W.D. (2001) Economics. 13th Edition, McGraw-Hill, New Yourk City, Chapters 21 and 22.

[21] Adesina, A.A. and Zinnah, M. (1993) Technology Characteristics, Farmers' Perceptions and Adoption Decisions: A Tobit Model Application in Sierra Leone. Agricultural Economics, 9, 297-311. https://doi.org/10.1111/j.1574-0862.1993.tb00276.x

[22] Langyintuo, A.S. and Mekuria, A. (2005) Accounting for Neighbourhood Influence in Estimating Factors Determining the Adoption of Improved Agricultural Technologies. American Agricultural Economics Association Annual Meeting, Providence, 24-27 July 2005.

[23] Feder, G., Just, R.E. and Zilberman, D. (1985) Adoption of Agricultural Innovations in Developing Countries: A Survey. Economic Development and Cultural Change, 33, 255-298. https://doi.org/10.1086/451461

[24] Abu, G.A., Djomo-Choumbou, R.F. and Okpachu, S.A (2011) Evaluating the Constraints and Opportunities of Maize Production in the West Region of Cameroon. Journal of Sustainable Development in Africa, 13, 189-196.

[25] Okoboi, G. (2012) Improved Inputs Use, Productivity and Commercialisation in Uganda Maize Production Globally 1996-2010. Landes Bioscience, 12, 265-272.

[26] Food and Agriculture Organisation (2006) Fertiliser Use by Crop. FAO Fertiliser and Plant Nutrition, Bulletin 17. Food and Agriculture Organisation, Rome.

[27] Conté, S. and Fusillier, J.-L. (1993) Analyse économique de la filière maïs au Cameroun. Direction des enquêtes agro-économiques de la planification agricole (DEAPA), Ministère de l'Agriculture, Yaoundé, $60 \mathrm{p}$.

[28] Adesina, A. and Baidu-Forson, A. (1995) Farmers' Perception and Adoption of New Agricultural Technology: Evidence from Analysis in Burkina Faso and Guinea, West Africa. Agricultural Economics, 13, 1-9. https://doi.org/10.1111/j.1574-0862.1995.tb00366.x

[29] Appleton, H. and Scott, A. (1994) Gender Issues in Agricultural Technological Development. Intermediate Technology Development Group, London.

[30] Department of Agriculture, Fisheries and Forestry (2012) Maize Market Value Chain Profile. Grain SA, Pretoria.

[31] Debertin, D.L. (2002) Choices and Development. Food and Agriculture Organisation, Rome. 
[32] Takeshima, H., Adeoti, A. and Popoola, O.A, (2016) The Impact on Farm Household Welfare of Large Irrigation Dams and Their Distribution across Hydrological Basins: Insights from Northern Nigeria. Nigeria Strategy Support Program Working Paper No. 35, Nigeria Strategy Support Program, Abuja.

[33] Adesina, A.A (1993) Perceptions, and Adoption Decisions: A Tobit Model Application in Sierra Leone. Productivity, and Crop Income. Agricultural Economics, 19, 219-229.

[34] Zeller, M., Diagne, A. and Mataya, C. (1998) Market Access by Smallholder Farmers in Malawi: Implications for Technology Adoption, Agricultural Productivity and Crop Income. Agricultural Economics, 19, 219-229.

https://doi.org/10.1111/j.1574-0862.1998.tb00528.x 